\title{
Service Policy of Puskesmas Based on Dempo Volcano Disaster Mitigation using AHP in Pagar Alam City - Indonesia
}

\author{
Linda Marni, Eri Barlian, Dedi Hermon, Indang Dewata, Iswandi Umar
}

\begin{abstract}
Pagar Alam City is one of the cities prone to disasters. So, the public health centre or we used to call it Puskesmas as the first aid health centre must be eligible. This research is used to formulate policies of Puskesmas eligibility, based on disaster mitigation of Dempo volcano eruption with Analytical Hierarchy Process (AHP) analysis. This eligible policy was Prepared using health workers, facilities and infrastructure and service systems as the main criteria. Furthermore, from these criteria, alternative policy choices have been agreed as follows: Improving the quality and readiness of the health workers $(40.2 \%)$, arranging mobilization and placement of health resources (20.9\%), creating a network of health services (12.5\%), developing a health service system for disaster preparedness (8.5\%), Increasing the cross-sectoral sector or between the institutions related to NGOs or the private sector (6.3\%), developing Puskesmas Disaster Plans (4.7\%), Increasing the capacity of facilities and infrastructure of Puskesmas in Pagar Alam City $(4,1 \%)$, and the Healthy Community Empowerment (2.7\%). This third priority can be implemented through strategy or implementation so that Puskesmas can carry out their role as optimal first aid services.
\end{abstract}

Keywords: policy, puskesmas, volcano dempo, pagar alam.

\section{INTRODUCTION}

Indonesia is a disaster-prone country and has the chances to experience natural, non-natural and social disasters, such as disasters: earthquakes, floods, volcano eruptions, fires, landslides, disease outbreaks, technological failures, social conflicts, and terrorism. These disasters, especially those related to tectonic earthquakes and volcano eruptions [1-3], resulted in emergencies, mass casualties and health problems in the community. Also, disaster events cause damage to public facilities, health facilities, disruption of communication channels and disrupt people's lives and

Revised Manuscript Received on May 15, 2020.

* Correspondence Author

Linda Marni*, his/her Program of Diploma III Nursing and doctoral program of environmental science, Universitas Negeri Padang, Padang, Indonesia. Email: lindamarni17@gmail.com

Eri Barlian, Department of doctoral program of environmental science, Universitas Negeri Padang, Padang, Indonesia. Email: eribarlian@unp.ac.id

Dedi Hermon, Department of geography and doctoral program of environmental science, Universitas Negeri Padang, Padang, Indonesia. Email: dihermon006@gmail.com

Indang Dewata, Department of doctoral program of environmental indangdewata@fmipa.unp.ac.id

Iswandi Umar, Department of geography and doctoral program of environmental science, Universitas Negeri Padang, Padang, Indonesia. Email: iswandi_u@yahoo.com

(c) The Authors. Published by Blue Eyes Intelligence Engineering and Sciences Publication (BEIESP). This is an open access article under the CC BY-NC-ND license (http://creativecommons.org/licenses/by-nc-nd/4.0/) science, Universitas Negeri Padang, Padang, Indonesia. Email:

livelihoods. Disaster mitigation is a disaster management effort to reduce the impact and reduce the risk of disaster [4]. [5] in every disaster event there are almost always brings the victims. Therefore, there needs to be readiness from the government and society preparedness in various fields. One of them is related to the availability and preparedness in the health sector, such as the presence or absence of the hospitals, Puskesmas and facilities service related to infrastructure including communication systems, the quality and quantity of human resources, as well as the completeness of emergency medical equipment. Health services in crisis conditions due to the disasters that have not been optimal, causing the services provided are still limited to the handling of general health problems.

In general, the impact of disasters will be felt more severely by vulnerable population groups. This is stated in Law Number 24 of 2007 concerning Disaster Management, that in the event of a disaster, vulnerable groups include: a) infants, toddlers and children; b) pregnant or nursing mothers; c) people with disabilities; and d) elderly people. In the process of rescue, evacuation, security to health and psychosocial services, the group becomes a priority [6-8].

Based on regulations and standards issued by the government, Puskesmas and other health personnel have an important role [9] in disaster management. Therefore, the Ministry of Health issued Decree No. 145/Menkes/SK/112007 concerning the Guidelines for Disaster Management in the Health Sector, which states that in the management of disasters in the health sector there is no policy to establish specific infrastructure, but rather to utilize existing facilities and infrastructure, by increasing work intensity by empowering all resources. government, community and other related private elements [9].

Furthermore, the Ministry of Health issues policy No. 1357/ Menkes/SK/XII/ 2001 concerning the role and tasks of Puskesmas in disaster management which has Minimum Standards for the management of health problems due to disasters and refugee Management, covering a) Health services, such as public health services, reproduction and mental health; b) prevention and eradication of communicable diseases; c) nutrition and food, including prevention of nutrition problems in refugee camps, nutritional surveillance, food quality and safety; d) environment, and e) relating to basic health needs, such as family shelter, clothing and household needs.

Blue Eyes Intelligence Engineering \& Sciences Publication DOI: 10.35940/ijmh.I0847.054920 
There are 7 units of Puskesmas in the Pagar Alam City, consisting of 3 units of Nursing Centers and 4 units of Non-Nursing Centers spread in 5 subdistricts [10], so that in obtaining health services through Puskesmas, supporting Puskesmas, and village health posts are available. In addition to the Puskesmas, Pagar Alam City also has a Besemah Regional Public Hospital which is a class D fully accredited basic level hospital.

Dempo Volcano has been very active since the eruption of Mount Merapi in 2010. In 2006, Dempo Volcano was marked by the emergence of continuous tremors which then occurred phreatic eruptions. Furthermore, in 2009 there was an ash rain contains rather thick sulfur odour [11]. In 2015, the activity status of Dempo volcano was raised to Level II (Vigilant) due to an increase in activity which was shown visually and by seismic data especially the Blowing earthquake [11]. Based on the history of the Dempo Volcano activity, it is known that the frequency of eruption of Dempo Volcano is irregular, has a resting period and eruption periods that are not fixed. Therefore, it is necessary to immediately do disaster mitigation in the health sector, to improve the feasibility of the existing Puskesmas and reduce the number of disaster victims. This study aims to develop a feasibility policy for Puskesmas based on the eruption of Mount Dempo eruption disaster, Pagar Alam City.

\section{RESEARCH METHODOLOGY}

This type of research is a descriptive study using AHP analysis. AHP is one method in a decision-making system that uses several variables with a multilevel analysis process. The analysis is done by giving priority values of each variable, then making pairwise comparisons of the variables and alternatives that exist [5, 12-15].

AHP method has 3 main principles in problem-solving, i.e decomposition, comparative judgment, and logical consistency [15]. These criteria and alternatives are carried out comparative judgment using the pairwise scale of interest comparison [14]. The steps taken in AHP [5, 14] are as follows: a) determine the criteria that are the focus of achieving the goal; b) determine the weight of each criterion through expert judgment; c) Calculate the weight of each criterion using the pairwise comparisons method; and d) determine policy priorities based on the greatest value.

Table-I: Banding Scale in Pairs

\begin{tabular}{cl}
\hline Value & \\
\hline 1 & Equally important \\
3 & Somewhat more important one over other \\
5 & Quite important \\
7 & Very important \\
9 & Extreme smoothness \\
$2,4,6,8$ & The Middle value between two adjacent decisions \\
\hline
\end{tabular}
Source [12-15]

The data to be analyzed by AHP was obtained from interviews and Focus Group Discussions (FGD) by inviting specialist/experts in their fields, such as the Department of Health, Higher Education engaged in health, BPBD, NGOs and the community. The results of these data are processed using Expert choice. This expert choice is one of the Decision Support System (DSS) applications that are used to determine a decision with many criteria. The selection of this application, based on consideration of its use is relatively easy and can be used freely for several predetermined criteria.

\section{RESULT}

Health services during disasters become very important factors to prevent and reduce the occurrence of death, disability and disease events, as well as reducing the impact caused [16]. One of the health services at the time of the disaster was carried out by the Puskesmas under the coordination of the regency/city health office [17].

The magnitude of the role of the Puskesmas in dealing with disasters drives the government to issue a policy so the Puskesmas can complete its tasks and functions well in the event of a disaster, including the role of health workers who are responsive and ready to deal with disaster victims communities [18]. Several studies have shown that nurses have lower levels of knowledge about disasters [19] [20]. Good ability in dealing with disaster victims is very much demanded by health centre health workers.

Earthquake victims not only experience emergency problems such as construction, food, physical condition due to the earthquake but also mental health problems [21]. After the disaster, most victims still have normal psychological reactions, but around 15-20\% will experience mild mental disorders and 3-4\% will experience severe disorders such as psychosis, severe depression and high anxiety [22]. Research shows that after the earthquake in Japan in 2011, mental health problems in PTSD were found to be around 10-53.5\% experienced by earthquake victims, while depressive conditions were experienced by around $3-43.7 \%$ of earthquake victims [23]. The condition will get worse if it is not detected early and handled properly so that it requires mental health services (trauma healing) [24].

In this study, the policy to improve the feasibility of the Public Health Center as a mitigation measure in disaster management in the field of health is determined based on the results of interviews and literature studies, so that three criteria are obtained. These criteria consist of human resources/health workers, facilities and infrastructure, and the community/disaster victims. These three criteria were chosen because in disaster management in the field of health by increasing the eligibility of Puskesmas as first aid, health workers as a helper become the main criteria, facilities and infrastructure as supporting the performance of health workers, and service systems that fall victim to disasters as objects to be served. Therefore, the criteria generated alternative policies as follows:

1. Increasing inter-sectoral or inter-agency coordination by involving NGOs or the private sector: The Government of Pagar Alam City needs to establish coordination with other agencies such as the Health Office, BPBD, PMI, NGOs, and the private sector to compile a plan that needs to be done in the event of a disaster-related to the needs of the Puskesmas.

Blue Eyes Intelligence Engineering \& Sciences Publication

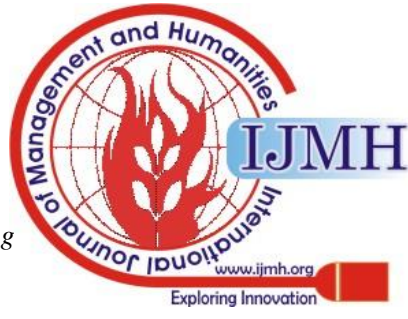


2. Increasing the capacity of facilities and infrastructure available at all Puskesmas in Pagar Alam City: Emphasis on the number of victims can be done if the population data is well documented and the availability of adequate infrastructure is taking into account the number of the population served and the radius of service.

3. Arrangement of mobilization and placement of health resources: Mobilization and placement of health resources are aimed at addressing disparities in health between regions. Health workers who have received training will apply mental health services as a form of meeting long-term and sustainable service needs that are part of efforts to improve the health system in the community [25].

4. Improving the quality and readiness of health workers: Health workers in charge of providing disaster services are dedicated staff so that the needs of the health services needed by the community are met.

5. Creating a network of health services: Networking with other sectors outside of health that is indispensable during disaster response services based on the ability of available health facilities by taking into account their abilities (quantity and quality).

6. Develop a mental health service system for disaster preparedness: Mental health services are needed by disaster victims to overcome psychological problems such as trauma and depression.

7. Empowering Healthy Communities: Community empowerment can be done by increasing the knowledge and ability of the community and health workers to be able to work together in identifying problems, planning and solving them by utilizing the local potential and existing facilities, both from cross-sectoral agencies, NGOs and community leaders.

8. Develop Puskesmas Disaster Plan: Puskesmas play a major role in the first rescue and management of disaster victims so that proper planning is needed so that it will continue to function well with the arrival of several patients as a result of an emergency as well as for patients who have been there before.

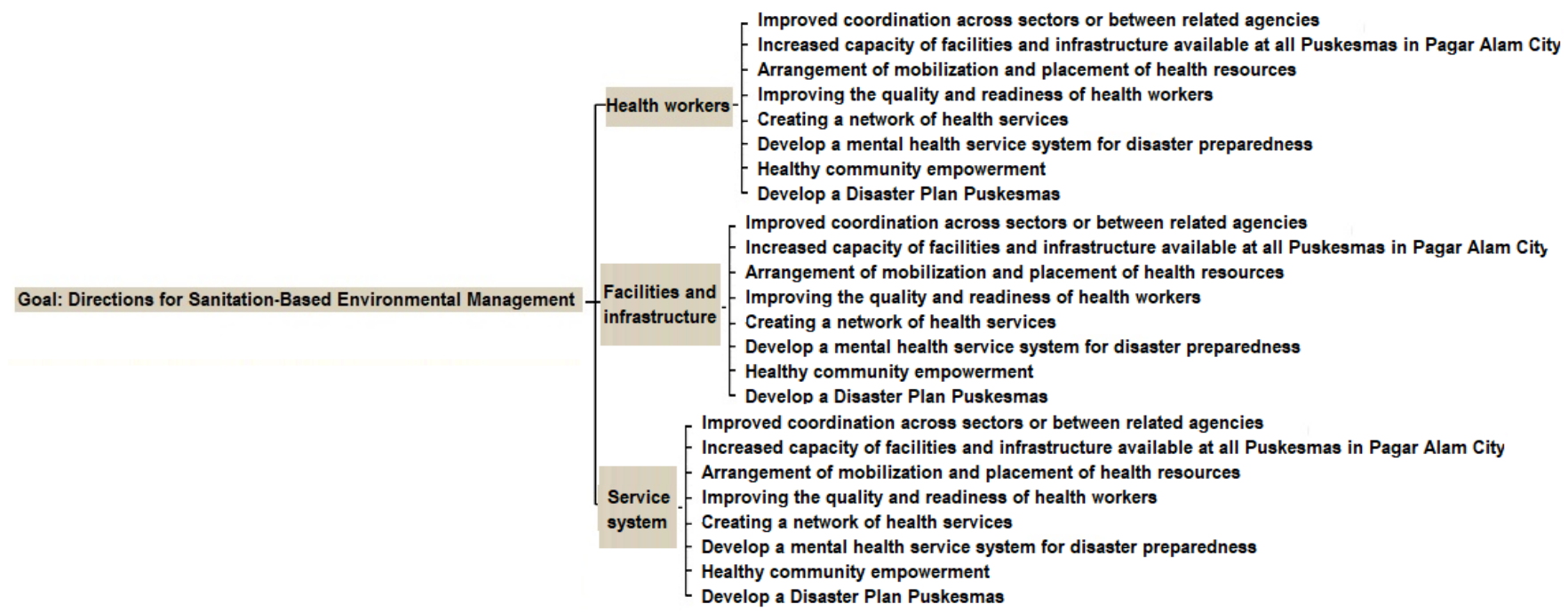

Fig. 1. Policy hierarchy

Priorities with respect to:

Goal: Feasibility of Puskesmas based on Dempo Volcano Eruption Disaster Mitigation

Health workers
Facilities and infrastructure
Service system
Inconsistency $=\mathbf{0 . 0 4}$

.637

.105

.258

with 0 missing judgments.

\section{Fig. 2. Weight of Interest Between Criteria and Consistency Policy}

The criteria and the eight alternative policies described in the policy hierarchy (Fig. 1) above show that to suppress victims of a disaster that will occur in Pagar Alam City, it can be done with mitigation or prevention measures through increasing the feasibility of Puskesmas. The Government of Pagar Alam City can turn a Puskesmas in its area into a viable and disaster preparedness Puskesmas, through the making of a Puskesmas feasibility improvement policy.

Policy hierarchies describe complex problems and then broken down into groups so that they appear more structured and systematic [26]. Therefore, the main goal or objective in the hierarchy is the feasibility of a Puskesmas based on the eruption of the Dempo volcano disaster. The policy is focused on three criteria, namely health workers, facilities and infrastructure and service systems, each of which has an alternative policy as a way to realize the policy goals or objectives.

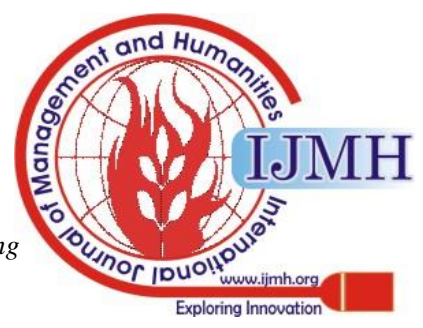


In compiling to determine alternative policies that can be prioritized, a pair of criteria were previously analyzed between the criteria, where the expert/specialist / adept will give a weighting assessment of the importance of the criteria between the criteria [27-29]. In Fig. 2, it is known that in improving the feasibility of Puskesmas, the main key is health workers, while still paying attention to the service system and facilities and infrastructure. In addition to the importance of inter-criteria weighting, the policy that has been given the assessment has a consistency value $<0.1$ that is 0.04 , which explains the weights given consistently, so that the order of priority that will be generated, is not in doubt as needed.

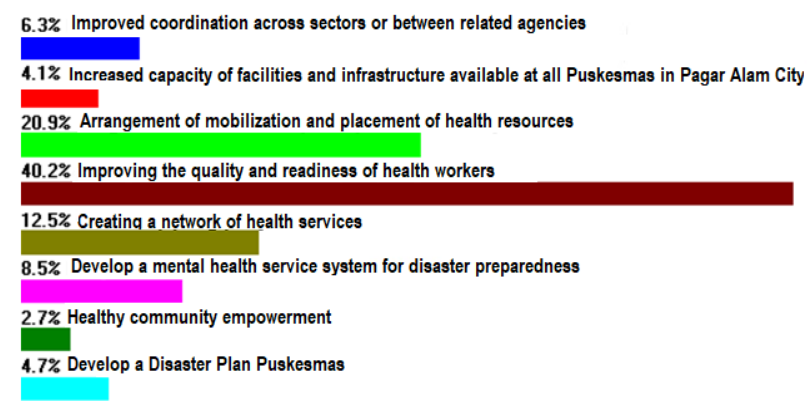

Fig. 3. Policy Priorities

Alternative policies that have been given an assessment weight produce policy priorities (Fig. 3) in a row as follows: Improving the quality and readiness of health workers (40.2\%), Arranging mobilization and placement of health resources (20.9\%), Creating a service network health (12.5\%), Develop a mental health service system for disaster preparedness (8.5\%), Increase cross-sectoral coordination or between related agencies by involving NGOs or the private sector (6.3\%), Develop a Disaster Plan Puskesmas (4, 7\%), increasing the capacity of facilities and infrastructure available at all Puskesmas in Pagar Alam City (4.1\%), and Empowering Healthy Communities (2.7\%). Of the eight alternative policies, only 3 were the main priorities. This is because, in its application, not all policies can be implemented, because of the limited time and cost. These three priorities can be realized through the following strategies:

1. Improving the quality and readiness of health workers

2. Arrangement of mobilization and placement of health resources

3. Creating a network of health services

The Puskesmas has a role in providing a first-aid health service system and is under the coordination of the Pagar Alam City Health Office. In the Republic of Indonesia Minister of Health Regulation No. 75 of 2014 concerning Community Health Centers, it is known that the types of health workers that must be in the Puskesmas consist of at least a doctor or primary service doctor, dentist, nurse, midwife, public health worker, environmental health worker, medical laboratory technology expert, nutrition and pharmaceutical staff. However, not all health centres that meet the minimum requirements for health workers, including in Pagar Alam City.

Puskesmas in Pagar Alam generally only have general practitioners, midwives and nurses. From 338 Puskesmas in South Sumatra, there are still many Puskesmas that do not have Nutritionist, Medical Laboratories and Dentists or more than $50 \%$ [30]. Inequality in the health workforce occurs, because villages and cities have different sociological, geographical, population, facilities and infrastructure, making standardization of the need for health workers in Puskesmas and hospitals quite difficult [31]. Whereas the quality of health services depends on the availability, type, and the number of health workers, which in turn is influenced by public policies regarding the distribution of health workers [32]. Therefore, for Puskesmas to carry out their roles as optimal first aid services, the three policy priorities above need to be implemented immediately. Given the still low readiness of health centres in dealing with disasters.

\section{CONCLUSION}

high risk and potential for disasters in the Pagar Alam City make Puskesmas as a private health service for the first level. Eight alternative policies can become the government's priority to improve the feasibility of Puskesmas based on Dempo volcano eruption in the following order: Improving the quality and readiness of health workers (40.2\%), Arrangement of mobilization and placement of health resources (20.9\%), Creating a network of health services (12.5\%), Developing a mental health service system for disaster preparedness (8.5\%), Increasing cross-sectoral coordination or between related agencies by involving NGOs or the private sector (6.3\%), Developing Disaster Health Centers Plan (4.7\%), the Increased capacity of facilities and infrastructure available at all Puskesmas in Pagar Alam City (4.1\%), and Empowering Healthy Communities (2.7\%). Of the eight alternatives that have become the order of priority, then due to time and cost constraints, only three policies have become the main priority in improving the feasibility of Puskesmas based on the Mount Dempo eruption disaster mitigation. These three priorities can be realized through existing strategies.

\section{ACKNOWLEDGEMENT}

This research was supported by Universitas Negeri Padang (UNP) and Pagar Alam City Government. We also thank of Chairman of Postgraduate UNP and Students involved in research for their support in this research.

\section{REFERENCES}

1. D. Hermon, Geografi Bencana Alam, Jakarta: Rajawali Pers, 2018

2. D. Hermon, Evaluation of Physical Development of the Coastal Tourism Regions on Tsunami Potentially Zones in Pariaman City-Indonesia. International Journal of GEOMATE, Vol.17, Issue.59, pp. 189-196. 2019

3. L. Arlym, D. Hermon, D. Lanin, O. Oktorie and A. Putra. A Policy Model of Preparedness The General Hospital in Reducing Victims of Earthquake and Tsunami Disasters in Siberut Mentawai Island, Indonesia. International Journal of Recent Technology and Engineering (IJRTE). Vol. 8. Issue 3. 2019

4. Hermon D. Mitigation and Adaptation DISASTER OF CLIMATE CHANGE. Sara Books Publication. 2019. Gujarat, India. 2019

5. Hermon, D., Ganefri, Erianjoni, Dewata, I., Iskarni, P and Syam. A. A Policy Model of Adaptation Mitigation and Social Risks The Volcano Eruption Disaster of Sinabung in Karo Regency-Indonesia. International Journal of GEOMATE, Vol.17, No.60, pp190-196. 2019 
6. Badan Nasional Penanggulangan Bencana (BNPB), Peraturan Kepala Badan Nasional Penanggulangan Bencana Nomor 7 Tahun 2008 tentang Pedoman Tata Cara Pemberian Bantuan Pemenuhan Kebutuhan Dasar, Jakarta:BNPB, 2008

7. D. Hermon, The Strategic Model of Tsunami Based in Coastal Ecotourism Development at Mandeh Regions, West Sumatera, Indonesia. Journal of Environment and Earth Science, 6(4), 2016, pp.40-45. 2016

8. E. Barlian, D. Hermon and I. Umar, Kajian Dinamika Penduduk dan Dampaknya Terhadap Lingkungan di Kota Padang, 2011.

9. Departemen Kesehatan (Depkes), Keputusan Menteri Kesehatan R Nomor 145/Menkes/SK/1/2007 tentang Pedoman Penanggulangan Bencana Bidang Kesehatan. Jakarta: Depkes, 2007

10. Dinas Kesehatan Kota Pagar Alam, Profil Kesehatan Kota Pagar Alam, 2014

11. Kementerian Energi dan Sumber Daya Mineral Badan Geologi, 2017 Peningkatan Tingkat Aktivitas G. Dempo. [Online]. Available: https://vsi.esdm.go.id/index.php/gunungapi/aktivitas-gunungapi/1518-p eningkatan-tingkat-aktivitas-g-dempo

12. T.L. Saaty, Pengambilan Keputusan Bagi Para Pemimpin: Proses Hirarki Analitik untuk Pengambilan Keputusan dalam Situasi yang Kompleks., Pustaka Binaman Pressindo, 1993

13. S. Mulyono, Riset Operasi. Edisi Revisi, Lembaga Penerbit Fakultas Ekonomi Universitas Indonesia, Jakarta, 2007

14. I. Umar, I. Dewata, E. Barlian, D.Hermon and Y. Suasti, Priority Selection of Residential Development Areas with Flood Hazard in Limapuluh Kota District, West Sumatra. International Journal of GEOMATE, Vol. 15, Issue. 52, pp. 152-158, 2018

15. D. Hermon, Impacts of land cover change on climate trend in Padang Indonesia. Indonesian Journal of Geography, Vol. 46, Issue. 2, pp. 138-142. 2014

16. J. Heizer and B. Render, Manajemen Operasi, Jakarta: Salemba Empat, 2014

17. Menteri Kesehatan RI, Keputusan Menteri Kesehatan RI No.066/MENKES/SK/II/2006 Tentang Pedoman Manajemen Sumber Daya Manusia (SDM) Kesehatan Dalam Penanggulangan Bencana, 2006

18. Badan Nasional Penanggulangan Bencana (BNPB), Rencana Strategis BNPB Tahun 2015-2019, Jakarta, 2015b

19. S. Tatuil, C.K.F. Mandagi, and S. Engkeng, Kajian Peran Tenaga Kesehatan Dalam Kesiapsiagaan Bencana Banjir di Wilayah Kerja Puskesmas Tuminting Kota Manado, Idea Nursing Journal, pp. 1-8, 2015

20. D. Hermawati, U. Hatthakit, and A. Chowalit, Nurse's Preparedness of Knowledge and Skills in Caring for Patients Attacked by Tsunami and Its Relating Factors, 2010

21. K. Hammad, P. Arbon, and K. Gebbie, Emergency Nurses and Disaster Response: An Exploration of South Australian Emergency Nurses' Knowledge and Perception of Their Roles in Disaster Response, Australasian Emergency Nursing Journal, 2011

22. S. Surendra, Post-disaster mental health and psychosocial support: experience from the 2015 Nepal earthquake. WHO South-East Asia”, Journal of Public Health, 2017

23. WHO. Building back better. Sustainable mental health care after emergencies, Geneva: World Health Organization, 2013, Available: http://apps.who.int/iris/beatstream/10665/85377/1/978241564571_eng. pdf?u $a=1$

24. S. Ando, Mental health problems in a community after the Great East Japan Earthquake in 2011: a systematic review, Harv Rev Psychiatry, Vol. 25, Issue. 1, pp. 15-28, 2017

25. S. Surendra, Post-disaster mental health and psychosocial support experience from the 2015 Nepal earthquake. WHO South-East Asia, Journal of Public Health, 2017

26. T.L. Saaty, Analytic Hierarchy Process", Prosiding: Jurnal, Vol. VI of the AHP Series, RWS Publ, 2000, 2010, pp: 478, 2010

27. Y.P. Putri, E. Barlian, I. Dewata, T.A. Tanto, Arahan Kebijakan Mitigas Bencana Banjir Bandang di Daerah Aliran Sungai (DAS) Kuranji Kota Padang, Majalah Ilmiah Globe, Vol. 20, Issue. 2, pp. 87-98, 2018

28. D. Hermon, The Strategic Model of Tsunami Based in Coasta Ecotourism Development at Mandeh Regions, West Sumatera, Indonesia, Journal of Environment and Earth Science, Vol. 6, Issue. 4, pp. 40-45, 2016

29. I. Umar, I. Dewata, Mitigation Policy Directions In Flood Hazard Zone At Limapuluh Kota District, West Sumatra Province, Jurnal Pengelolaan Sumberdaya Alam dan Lingkungan, Vol. 8, Issue. 2, pp.251-257, 2018

30. Dinas Kesehatan Provinsi Sumatera Selatan, Profil Dinas Kesehatan Tahun 2017, 2017
31. R.K. Geswar, Nurhayani dan Balqis, Kesiapan Stakeholder Dalam Pelaksanaan Program Jaminan Kesehatan Nasional Di Kabupaten Gowa, 2013

32. S.L Barber, P.J. Gertler, P. Harimurti, "The contribution of human resources for health to the quality of care in Indonesia" Health Aff (Millwood), vol. 26, no. 3, 2007, pp. 67-79

\section{AUTHORS PROFILE}

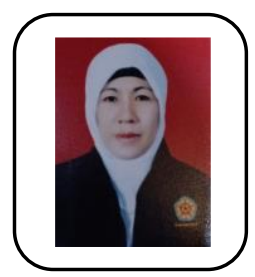

Linda Marni is a Research, Nurse and Lecturer of Diploma III Nursing, Universitas Negeri Padang, obtained the Master Degree in Health Managemen at STIE Indonesia Malang. He is actively involved in any researches regarded to environmental health and produces several scientific works in the form of SINTA-Indonesia indexed journals (ID: 6698643) Right now he is a student Doctoral Program of Environmental Science, Universitas Negeri Padang and is also a member of the Indonesian National Nurses Association DPD Padang Pariaman.

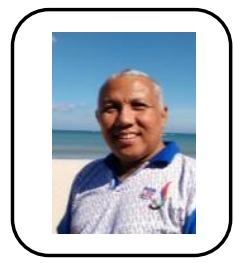

Eri Barlian is a Professor of Environmental Education, obtained the Doctorate Degree in Doctor Program Education Science at Universitas Negeri Jakarta, 1999. He is actively involved in any researches regarded to environmental education, sports, recreation and disaster and produces several scientific works in the form of Scopus indexed journals (ID: 57202293479). He is Chair of Doctoral Program of Environmental Science, Universitas Negeri Padang.

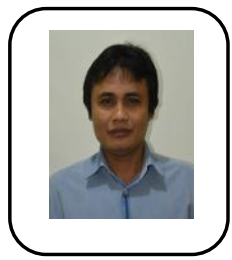

Dedi Hermon is a Professor of Disaster Geography, obtained the Doctorate Degree in Doctor Program Natural Resources Management and Environment at Bogor Agriculture University, 2009. He is actively involved in any researches regarded to natura disaster, land cover, carbon stock and produces several scientific works in the form of Scopus indexed journals (ID: 57200409691) and scientific books both national and international publications. He is assistant director of Postgraduate Universitas Negeri Padang as well as the head of Study Center of Disaster and Environment, Universitas Negeri Padang.

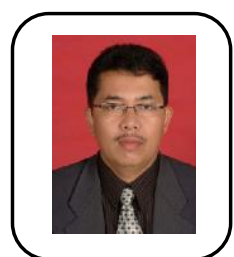

Indang Dewata is an Associate professor of Environmental Science, obtained the Doctorate Degree in Doctor Program Education Science at Universitas Indonesia, 2009. He is actively involved in any researches regarded to environmental science, chemical and produces several scientific works in the form of Scopus indexed journals (ID: 57202287960).

He is Chair of Masters Program of Environmental Science, Universitas Negeri Padang.

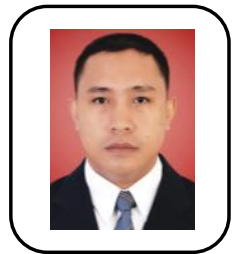

Iswandi Umar is an Associate professor of Environmental Science, obtained the Doctorate Degree in Doctor Program Natural Resources Management and Environment at Bogor Agriculture University, 2015. He is actively involved in any researches regarded to environmental science, geography and produces several scientific works in the form of Scopus indexed journals (ID: 57204825796). He is Chair of Masters Program of Geography Education, Universitas Negeri Padang.

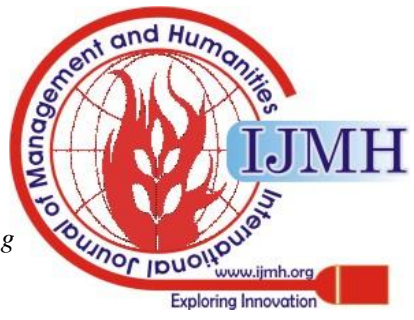

